\title{
Teaching NeuroImages: Pupil-sparing oculomotor nerve palsy with posterior communicating artery aneurysm
}

Hee Kyung Yang, MD, * Jae Hyoung Kim, MD,* and Jeong-Min Hwang, MD

Neurology ${ }^{\circledR}$ 2020;95:e1443-e1444. doi:10.1212/WNL.0000000000010152

Figure Ocular versions, pupillography, brain MRI, and cerebral angiography

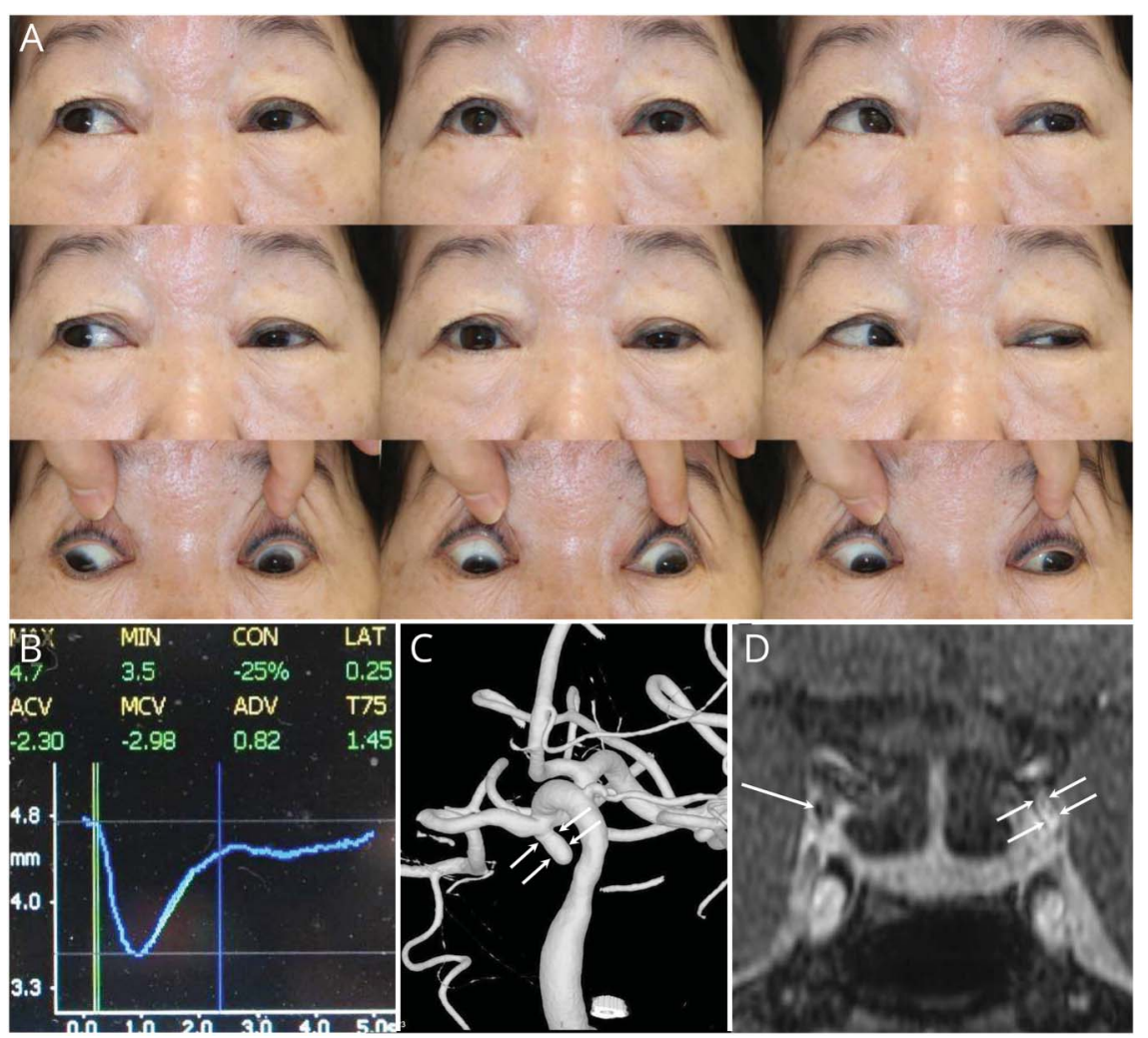

(A) Ocular versions demonstrating limited adduction, elevation, and depression, and ptosis OS. (B) Pupillography showing a normal pupillary light response in the left eye. (C, D) Brain MRI and transfemoral cerebral angiography revealed left posterior communicating artery aneurysm ( $5 \mathrm{~mm}$ sized) with inferior projection (arrows) compressing the left oculomotor nerve traversing the left cavernous sinus.

A 66-year-old woman presented with ptosis and diplopia 2 weeks prior. She showed ptosis and limited adduction, elevation, and depression in the left eye (figure, A). Her pupils were isocoric and reactive (figure, B). Transfemoral left internal carotid angiography (figure, C) revealed a 5-mm elongated aneurysm with inferior projection (arrows) at the posterior communicating artery origin. Contrast-enhanced thin-section T1-weighted coronal image (figure, D) showed the aneurysm (short arrows) compressing the left oculomotor nerve at the cavernous sinus. The right

\section{Correspondence}

Dr. Hwang

hjm@snu.ac.kr

\section{MORE ONLINE}

$\rightarrow$ Teaching slides

lww.com/WNL/B154

*These authors contributed equally to this work.

From the Departments of Ophthalmology (H.K.Y., J.-M.H.) and Radiology and Neurology (J.H.K.), Seoul National University College of Medicine, Seoul National University Bundang Hospital, Seongnam, Gyeonggi, Korea.

Go to Neurology.org/N for full disclosures. Funding information and disclosures deemed relevant by the authors, if any, are provided at the end of the article. 
oculomotor nerve traversing in the cavernous sinus was normally well identified as a round low signal (long arrow). This case violates the "rule of the pupil" proven with pupillography.

\section{Study funding}

No targeted funding reported.

\section{Disclosure}

The authors report no disclosures relevant to the manuscript. Go to Neurology.org/N for full disclosures.

\section{Appendix Authors}

\begin{tabular}{|c|c|c|}
\hline Name & Location & Contribution \\
\hline $\begin{array}{l}\text { Hee Kyung } \\
\text { Yang, MD }\end{array}$ & $\begin{array}{l}\text { Seoul } \\
\text { National } \\
\text { University }\end{array}$ & $\begin{array}{l}\text { Designed and conceptualized study, } \\
\text { major role in the acquisition of data, } \\
\text { analyzed the data, drafted the } \\
\text { manuscript for intellectual content }\end{array}$ \\
\hline
\end{tabular}

Appendix (continued)

\begin{tabular}{lll}
\hline Name & Location & Contribution \\
\hline $\begin{array}{l}\text { Jae Hyoung } \\
\text { Kim, MD }\end{array}$ & $\begin{array}{l}\text { Seoul } \\
\text { National } \\
\text { University }\end{array}$ & $\begin{array}{l}\text { Interpreted the data, revised the } \\
\text { manuscript for intellectual content }\end{array}$ \\
\hline $\begin{array}{l}\text { Jeong-Min } \\
\text { Hwang, MD }\end{array}$ & $\begin{array}{l}\text { Seoul } \\
\text { National } \\
\text { University }\end{array}$ & $\begin{array}{l}\text { Designed and conceptualized } \\
\text { study, analyzed the data, revised } \\
\text { the manuscript for intellectual } \\
\text { content }\end{array}$ \\
\hline
\end{tabular}

\section{References}

1. Trobe JD. Third nerve palsy and the pupil: footnotes to the rule. Arch Ophthalmol 1988;106:601-602.

2. Kim HM, Yang HK, Hwang JM. Quantitative analysis of pupillometry in isolated third nerve palsy. PLoS One 2018;13:e0208259. 


\section{Neurology}

\section{Teaching NeuroImages: Pupil-sparing oculomotor nerve palsy with posterior communicating artery aneurysm}

Hee Kyung Yang, Jae Hyoung Kim and Jeong-Min Hwang

Neurology 2020;95; e1443-e1444 Published Online before print July 8, 2020

DOI 10.1212/WNL.0000000000010152

This information is current as of July 8, 2020

\section{Updated Information \&} Services

\section{References}

Subspecialty Collections

Permissions \& Licensing

Reprints including high resolution figures, can be found at: http://n.neurology.org/content/95/10/e1443.full

This article cites 2 articles, 0 of which you can access for free at: http://n.neurology.org/content/95/10/e1443.full\#ref-list-1

This article, along with others on similar topics, appears in the following collection(s):

MRI

http://n.neurology.org/cgi/collection/mri

Ocular motility

http://n.neurology.org/cgi/collection/ocular_motility

Information about reproducing this article in parts (figures,tables) or in its entirety can be found online at:

http://www.neurology.org/about/about_the_journal\#permissions

Information about ordering reprints can be found online:

http://n.neurology.org/subscribers/advertise

Neurology ${ }^{\circledR}$ is the official journal of the American Academy of Neurology. Published continuously since 1951, it is now a weekly with 48 issues per year. Copyright (O) 2020 American Academy of Neurology. All rights reserved. Print ISSN: 0028-3878. Online ISSN: 1526-632X.

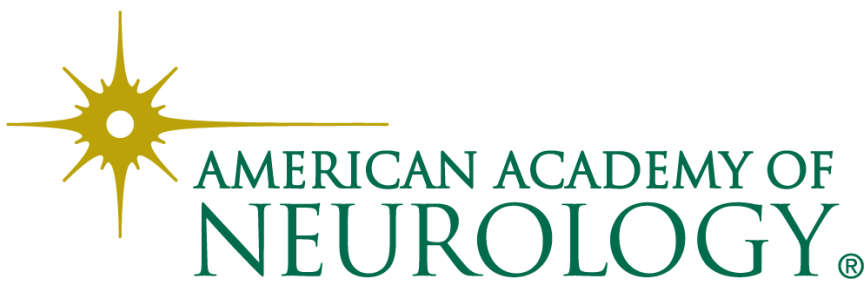

